REVIEW

\title{
When should we thrombolyse patients with pulmonary embolism? A systematic review of the literature
}

\author{
T Harris, S Meek
}

Emerg Med J 2005;22:766-771. doi: 10.1136/emj.2003.011965

The early mortality in pulmonary embolism (PE) is largely predicted by the associated cardiovascular response, with progressive right ventricular failure, hypotension, shock, and circulatory arrest being associated with increasing mortality. Thrombolysis may improve the prognosis of PE associated with these varying degrees of circulatory collapse, but has no place in the treatment of small emboli with no cardiovascular compromise, as it carries a significant risk of haemorrhage. This review sets out to guide the emergency physician in deciding which patients with PE may benefit from thrombolysis.

See end of article for authors' affiliations

Correspondence to: Dr T Harris, Senior

Registrar in Intensive Care, Royal Melbourne Hospital, Melbourne, Australia; timreharris@yahoo.com

Accepted for publication 21 October 2004
$\mathrm{P}$ ulmonary embolism (PE) remains a common disease, with an incidence of about 6070 per 100000 of the general population. ${ }^{1}$ Postmortem studies, which reflect disease in the whole hospital rather than the emergency department (ED) population, have found that only $30-45 \%$ of those who died of PE had the correct antemortem diagnosis. ${ }^{2-4}$ This suggests that although over $80 \%$ of patients have a risk factor such as previous thromboembolic disease, immobilisation, morbid obesity, malignancy, cardiac failure, pregnancy, or recent surgery, $\mathrm{PE}$ is underdiagnosed and physicians should have a lower threshold for considering the disease.

Hull $^{6}$ diagnosed PE in $21 \%$ of those patients presenting to the ED with pleuritic chest pain. PE associated with reduced cardiac output or right ventricular embarrassment is suggested by nonspecific findings including dyspnoea, syncope, hypotension, tachycardia, loud second heart sound (P2), and cyanosis.

This review will concentrate on assessing which patients with pulmonary embolism would benefit from thrombolysis.

\section{SEARCH STRATEGY}

An electronic search was performed using once with Ovid) and Embase (1980-2002) using the terms pulmonary embolism, thromboembolism combined with each named thrombolytic agent, thrombolysis, right heart strain/failure, pulmonary hypertension, and shock. This was later repeated using the search engine Google. Relevant papers were obtained and references from these were inspected. No authors were contacted and no unpublished data were obtained. MedLine (1966-2002; once with PubMed and

\section{TREATMENT OPTIONS FOR PE}

There are no robust data on the untreated overall mortality of PE, as heparin was introduced in the 1960s before modern imaging was widely available, and thus no placebo arm is included in modern trials. The mortality has been quoted at $\sim 30 \%$, which is reduced to $1-15 \%$ with anticoagulation. $^{7-9}$ Recently, low molecular weight heparins have proved to be as effective as or superior to intravenous heparin infusion. ${ }^{10-12}$

Anticoagulation with heparin prevents clot propagation, tipping the balance in favour of endogenous fibrinolysis and allowing clot dissolution over weeks and months. ${ }^{13}$ Thrombolytics are plasminogen activators, converting plasminogen to plasmin, which then degrades clot bound fibrinogen, resulting in clot lysis. Thrombolysis may result in faster and more complete clot lysis, producing a more rapid improvement in pulmonary flow, right ventricular performance, and oxygenation, which could lower morbidity and mortality. ${ }^{14}$ The causal clot may also be more efficiently lysed and so recurrence reduced. However, thrombolysis risks haemorrhage. Is there a subset of patients at high risk of death in whom the potential benefits outweigh the risk?

\section{CAN WE PREDICT WHO IS MOST AT RISK OF DEATH FROM PE?}

It is intuitive that large pulmonary emboli in patients with less cardiorespiratory reserve should result in higher mortality. Death occurs from circulatory obstruction, causing right heart failure, systemic shock, and hypoperfusion. In 1976. Alpert found that the presence of right ventricular (RV) failure rather than embolic size determined mortality. Alpert followed 144 patients with angiographically proven $\mathrm{PE}$ and found a mortality of 20 (13.8\%), of whom 8 were thought to have died despite the PE and 12 (8\%) because of it. Nine (75\%) of this group had RV failure but the degree of arterial obstruction varied from 25 to $75 \%$. The mortality of those with $>50 \%$ arterial occlusion on angiogram was $6 \%$ in those with no acute right heart failure and $32 \%$ where RV failure was present. ${ }^{15}$

In 1993, Goldhaber suggested that echocardiographic evidence of RV wall motion abnormality could define a high risk subgroup. ${ }^{16}$ The International Cooperative Pulmonary Embolism Registry was set up specifically to look at factors

Abbreviations: CPR, cardiopulmonary resuscitation; ED, emergency department; PE, pulmonary embolism; rTPA, recombinant tissue plasminogen activator; RV, right ventricular 
associated with 3 month mortality from PE. ${ }^{\text {Data }}$ were obtained on 2454 patients from 52 North American and European centres, relying on diagnostic information supplied by the centres.

The following predicted mortality on multiple regression modelling: (a) age $>70$ years (hazard ratio (HR) $1.6 ; 95 \%$ confidence interval (CI) 1.1 to 2.3); (b) cancer (HR 2.3 CI 1.5 to 3.5 ); (c) congestive cardiac failure (HR 2.4 CI 1.5 to 3.7); (d) systolic hypotension (HR 2.9 CI 1.7 to 5.0 ); (e) tachypnoea (HR 2.0 CI 1.2 to 3.2); and ( $f$ ) RV hypokinesis on echo (HR 2.0 CI 1.3 to 2.9 ).

The mortality in the haemodynamically unstable (not defined) group was 56 of 96 (58.3\%), compared with 317 of 2093 patients $(15.1 \%)$ who were haemodynamically stable. RV hypokinesis on echo was also associated with higher mortality.

The Management Strategy and Prognosis of Pulmonary Embolism Registry included 1001 patients from 204 German centres divided into 4 subgroups based on cardiac performance. ${ }^{17}$ Overall mortality was as follows:

- Group 1: normotensive group but with pulmonary hypertension or RV dysfunction on echocardiogram. Mortality $8.1 \%$.

- Group 2: systemic hypotension (systolic blood pressure $<90$ or pressure drop $>40$ ). Mortality $15 \%$.

- Group 3: cardiogenic shock. Mortality 25\%.

- Group 4: those requiring cardiopulmonary resuscitation. Mortality 65\%.

In a separate study of 317 patients with clinically suspected $\mathrm{PE}$, Kasper ${ }^{18}$ found the in hospital/1 year mortality from PE was $13 \% / 13 \%$ in those with echocardiographic evidence of RV dysfunction and $0.9 / 1.3 \%$ in those without. In this study, transthoracic echocardography was used, with one of the A criteria or two of the B criteria being used to diagnose RV dysfunction (table 1).

If those with acute rather than chronic RV afterload stress are considered alone, then the in hospital mortality rises to $23.5 \%$ in this study. Thus the acute mortality of PE is largely dependent on the resulting cardiovascular performance, being worst if the patient is in arrest, better if the patient is in shock, better still if normotensive with RV dysfunction, and best of all with normal pulmonary and systemic haemodynamics.

The simplest way to determine RV function in the ED is by echo. It may also help identify other causes of chest pain and cardiovascular embarrassment such as myocardial infarction and aortic dissection. Its use in the emergent assessment and triage of patients with $\mathrm{PE}$ has been advocated by Konstantinides. ${ }^{19}$

\section{WHAT IS THE EVIDENCE FOR THE USE OF THROMBOLYSIS IN PE?}

The literature search identified 10 randomised trials comparing thrombolysis to heparin in patients with PE as outlined in table 2. Five trials excluded patients with shock (defined usually as systolic blood pressure $<90 \mathrm{mHg}$ ). Nine delivered the thrombolysis intravenously and one delivered it into the

Table 1 Criteria for RV dysfunction

A criteria: right ventricle appearing larger than left ventricle or right ventricle end diastolic diameter $>30 \mathrm{~mm}$

B criteria: tricuspid regurgitation jet velocity $>2.8 \mathrm{~m} / \mathrm{s}$ or $>2.5 \mathrm{~m} / \mathrm{s}$ in absence of IVC inspiratory collapse, pulmonary artery $>12 \mathrm{~mm} / \mathrm{m} 2$ body area or RV wall $>5 \mathrm{~mm}$ or loss of insipratory collapse of the inferior vena cava pulmonary artery. Five used rTPA, three streptokinase, and two urokinase. None used tenecteplase. Only one trial looked specifically at patients with shock ${ }^{28}$ and one investigated patients without shock but with ECG/right cardiac catheter/ echo evidence of right heart strain or pulmonary hypertension or RV dysfunction. ${ }^{29}$

The first nine trials in the table, which involved 461 patients in total, were included in a meta-analysis by Thabut et al in 2002, ${ }^{30}$ which concluded that in this unselected group of patients the use of thrombolytics to treat PE was not associated with a reduction in mortality (relative risk (RR) $0.63 ; 95 \%$ CI 0.32 to 1.23 ) or disease recurrence ( $R R=0.59$; $95 \%$ CI 0.30 to 1.18 ) but did confer a risk of haemorrhage over heparin ( $\mathrm{RR}=1.76$; $95 \%$ CI 1.04 to 2.98). Major haemorrhage is defined here as intracerebral, retroperitoneal, or other bleeding requiring surgery or a blood transfusion. A further meta-analysis of the same 461 patients and 9 trials by Agnelli and colleagues, ${ }^{31}$ also published in 2002, concluded that thrombolytic therapy conferred no mortality advantage over heparin, ( $\mathrm{RR}=0.59 ; 95 \% \mathrm{CI} 0.27$ to 1.25$)$ but also resulted in no change in disease recurrence $(R R=0.60 ; 95 \%$ CI 0.29 to 1.15$)$ or risk of major haemorrhage $(\mathrm{RR}=1.49$; $95 \%$ CI 0.85 to 2.81 ). In this paper, major haemorrhage was defined as fatal, intracranial, associated with a decrease in haemoglobin of at least $20 \mathrm{~g} / \mathrm{l}$, or requiring a transfusion of two or more units of red blood cells. Agnelli et al also examined the combined endpoint of recurrence and/or death, which occurred in $25 / 241(10.4 \%)$ of patients thrombolysed and 38/220 (17.3\%) treated with heparin. This gives a significantly lower relative risk of death/recurrence $(\mathrm{RR}=0.55 ; 95 \%$ CI 0.33 to 0.96$)$.

These meta-analyses involved relatively few patients, and the inclusion of so many trials where "shock" was an exclusion criterion weakens their power. With one exception, ${ }^{28}$ the other trials did not provide enough information to allow subset analysis of those with shock or RV dysfunction.

The trials on thrombolysis in PE may be underpowered to detect a true treatment mortality advantage, or alternatively the benefits of thrombolysis may outweigh the risks in only those few at high risk of death from PE. If thrombolysis is in fact effective, it is essential to use it in a subgroup where the potential benefit of therapy outweighs the risk.

\section{USE OF THROMBOLYSIS IN DIFFERENT GROUPS OF PATIENTS \\ Patients with PE and systemic hypotension}

The use of thrombolysis in this group is widely advocated, reflecting the high mortality rate and encouraging case reports. ${ }^{1417} 3233$ However, only one small randomised trial exists. In 1995, Jerges-Sanches et al ${ }^{28}$ compared thrombolysis with streptokinase to intravenous heparin in eight patients. The trial was stopped early, as all four patients thrombolysed lived whereas the four treated with heparin died.

There was a major difference between the two groups by chance; the four patients who had streptokinase were new presentations to the treating hospital. Those receiving heparin were already receiving heparin treatment in other hospitals for small emboli without compromise, when they suddenly suffered massive pulmonary emboli and were transferred to the trial centre.

\section{Patients with cardiopulmonary arrest}

The evidence base of much of what we offer for patients in arrest from PE is not substantiated by clinical trials. ${ }^{34}$ The mortality in this group has been reported as $65 \%$ in the MAPPET registry, ${ }^{17}$ and use of thrombolytics is widely advocated..$^{143}$ In 2001, Bailen ${ }^{37}$ reviewed the literature on thrombolysis for fulminant PE with circulatory collapse requiring cardiopulmonary resuscitation (CPR), and found 
Table 2 Randomised trials comparing thrombolytic and heparin therapy

\begin{tabular}{|c|c|c|c|c|c|c|}
\hline Study & Treatment regimens & $\begin{array}{l}\text { No. of } \\
\text { patients }\end{array}$ & $\begin{array}{l}\text { Mortality, } \\
\text { n (\%) }\end{array}$ & $\begin{array}{l}\text { Recurrence } \\
\text { n (\%) }\end{array}$ & $\begin{array}{l}\text { Major } \\
\text { haemorrhage, * n } \\
(\%)\end{array}$ & Comments \\
\hline \multirow[t]{2}{*}{ UPET $1970^{20}$} & IV heparin $v$ UK & 78 & $7(8.9)$ & $15(19)$ & $21(27)$ & Patients had $<5$ days of symptoms \\
\hline & $2000 \mathrm{U} / \mathrm{lb}$ bolus then hourly & 82 & $6(7.3)$ & $12(15)$ & $37(45)$ & $\begin{array}{l}\text { Angiography used to diagnose and } \\
\text { repeated at } 24 \text { hours showing } \\
\text { improved haemodynamics in UK } \\
\text { group }\end{array}$ \\
\hline \multirow[t]{2}{*}{$\begin{array}{l}\text { Tibbutt et al } \\
1974^{21}\end{array}$} & IP heparin & 17 & $1(5.8)$ & $1(5.8)$ & $1(5.8)$ & $\begin{array}{l}\text { SK group had greater improvement } \\
\text { in pulmonary perfusion }\end{array}$ \\
\hline & $\begin{array}{l}\text { IP SK } 600000 \text { units bolus then } \\
100000 \text { units/h for } 72 \text { hours }\end{array}$ & 13 & 0 & 0 & $1(8)$ & $\begin{array}{l}\text { All patients had life threatening PE } \\
\text { and angiographic diagnosis }\end{array}$ \\
\hline \multirow[t]{2}{*}{ Ly et al $1978^{22}$} & IV heparin $v$ APTT & 11 & $2(18.2)$ & NA & $2(18)$ & $\begin{array}{l}\text { Angiographic evidence of improved } \\
\text { perfusion with SK }\end{array}$ \\
\hline & $\begin{array}{l}\text { SK } 250000 \text { units bolus and } \\
100000 \text { units per hour } 72 \text { hours }\end{array}$ & 14 & $1(7.1)$ & & $4(29)$ & All patients $>1$ lobar artery occluded \\
\hline \multirow[t]{3}{*}{$\begin{array}{l}\text { Marini et al } \\
1988^{23}\end{array}$} & Heparin $v$ APTT & 10 & 0 & 0 & 0 & $\begin{array}{l}\text { Patients all }>9 \text { segments not perfused } \\
\text { on } Q \text { scan. By } 24 \mathrm{hrs} \text { and at } 1 \text { year } \\
\text { no difference in pulmonary } \\
\text { haemodynamics }\end{array}$ \\
\hline & $\begin{array}{l}\text { UK } 800000 \text { units } 12 \text { hourly for } \\
3 \text { days }\end{array}$ & 10 & 0 & 0 & 0 & \\
\hline & $\begin{array}{l}\text { UK } 3300000 \text { units for } \\
12 \text { hours }\end{array}$ & 10 & 0 & 0 & 0 & \\
\hline \multirow[t]{2}{*}{$\begin{array}{l}\text { PIOPED } \\
1990^{24}\end{array}$} & Heparin $v$ APTT & 4 & 0 & NA & 0 & $\begin{array}{l}\text { Vascular resistance better for rTPA } \\
\text { group at } 90 \text { mins but equal at } 2 \text { hrs }\end{array}$ \\
\hline & $\begin{array}{l}\text { rTPA } 40-80 \text { mg for } 40- \\
90 \text { minutes }\end{array}$ & 9 & $1(11.1)$ & & $1(11.1)$ & Patient diagnosis by angiogram \\
\hline \multirow[t]{2}{*}{$\begin{array}{l}\text { Levine et al } \\
1990^{25}\end{array}$} & Heparin $v$ APTT & 25 & 0 & 0 & 0 & $\begin{array}{l}\text { Perfusion scan on day } 1 \text { better with } \\
\text { rTPA but equal by day } 7\end{array}$ \\
\hline & rTPA $0.6 \mathrm{mg} / \mathrm{kg}$ over 2 minutes & 33 & $1(3)$ & 0 & 0 & Diagnosis by angiogram \\
\hline \multirow[t]{2}{*}{$\begin{array}{l}\text { PAIMS } 2 \\
1992^{26}\end{array}$} & Heparin $v$ APTT & 16 & $1(6.3)$ & $3(18.8)$ & $2(12.5)$ & $\begin{array}{l}\text { Haemodynamics better at } 24 \text { hours } \\
\text { in rTPA group but equal day } 7 \text { and } \\
30\end{array}$ \\
\hline & rTPA $100 \mathrm{mg}$ over 2 hours & 20 & $2(10)$ & $1(5)$ & $3(15)$ & \\
\hline \multirow[t]{2}{*}{$\begin{array}{l}\text { Goldhaber } \\
\text { et al } 1993^{27}\end{array}$} & Heparin $v$ APTT & 55 & $2(3.6)$ & $5(9.1)$ & $1(1.8)$ & $\begin{array}{l}\text { Perfusion scans and RV function on } \\
\text { echo better in rTPA at } 24 \text { hours }\end{array}$ \\
\hline & rTPA $100 \mathrm{mg}$ over 2 hours & 46 & 0 & 0 & $2(4.3)$ & \\
\hline \multirow[t]{2}{*}{$\begin{array}{l}\text { Jerges- } \\
\text { Sanches et al } \\
1995^{28}\end{array}$} & Heparin infusion $v$ APTT & 4 & $4(100)$ & NA & 0 & $\begin{array}{l}\text { All patients had shock. } 100 \% \\
\text { mortality in heparin group led to tria } \\
\text { being abandoned early }\end{array}$ \\
\hline & SK 1500000 units over 1 hour & 4 & 0 & & 0 & \\
\hline \multirow[t]{2}{*}{$\begin{array}{l}\text { Konstantinides } \\
\text { ef al } 2002^{29}\end{array}$} & Heparin infusion $v$ APTT & 138 & $3(2.2)$ & $4(2.9)$ & $5(3.6)$ & $\begin{array}{l}\text { Unexpectedly low mortality. } \\
\text { Composite end point of death or } \\
\text { treatment escalation lower in rTPA }\end{array}$ \\
\hline & rTPA 100 mg over 2 hours & 118 & $4(3.4)$ & $4(3.4)$ & $1(0.8)$ & Group: see text. \\
\hline
\end{tabular}

*Defined as intracranial bleed, bleed requiring surgery, transfusion or fall $>10 \%$ in haematocrit. IV, intravenous; IP, intrapulmonary; U, units; SK, streptokinase; UK, urokinase; rTPA, recombinant tissue plasminogen activator, infusion followed by intravenous heparin.

about 100 case reports and a retrospective series of 42 patients. In this series, 21 patients received heparin and 21 received thrombolytics, resulting ih no mortality difference but a higher return of spontaneous circulation in favour of thrombolysis. Many of this group were young postoperative or postpartum cases. The high number of survivors and paucity of haemorrhagic complications coupled with the poor prognosis of this group suggests that the use of thrombolysis may be beneficial in this setting.

In their 1999 review (predominantly of case reports), Newmann et $a l^{35}$ found a survival rate of $75 \%$ (50/67) for patients given thrombolysis after undergoing CPR for varied aetiologies. Many of these cases were characterised by long periods of CPR, with surprisingly good neurological recovery. However, this type of study is likely to suffer from reporting bias. Newmann proposes that thrombolysis may have neuroprotective properties through lysing microvascular thrombi and improving cerebral microvascular flow. The use of thrombolysis in arrested patients of unknown cause has been proposed, as the majority are due to thrombolytic responsive disease, coronary ischaemia, or PE..$^{35}$ Causes such as subarachnoid or intracerebral haemorrhage are contraindications for thrombolysis, but patient prognosis in this setting is dismal and other contraindications such as trauma or gastrointestinal haemorrhage are readily identifiable.
Bottiger $^{36}$ performed a nonrandomised prospective trial comparing $50 \mathrm{mg}$ of rTPA and intravenous heparin with conventional CPR/advanced life support and no anticoagulation in patients with $>15$ minutes of arrest (repeated at 30 minutes if no return of spontaneous circulation occurred), and found an improved rate of return of spontaneous circulation $(68 \% v 44 \%)$ and higher rate of hospital discharge $(15 \% \vee 8 \%)$ in the treatment arm. Based on this protocol, eight arrested patients would require treatment with thrombolytics to result in one extra survivor.

\section{Patients with PE and with RV dysfunction}

$\mathrm{RV}$ dysfunction has been shown to predict disease recurrence and mortality as detailed above. In a randomised controlled trial, Goldhaber ${ }^{16}$ found RV function improved at 24 hours in 16/18 thrombolysed patients compared with $8 / 18$ treated with heparin.

Konstantinides ${ }^{19}$ found a 30 day mortality of $4.7 \%$ in 169 patients who received thrombolysis, compared with $11.1 \%$ in 550 who were treated with heparin. Recurrence rates were $7.7 \%$ and $18.7 \%$ respectively. These data were from a multicentre registry (not a randomised trial) of 719 patients with echo or cardiac catheter evidence of RV dysfunction or pulmonary hypertension but systolic pressures $>90 \mathrm{mmHg}$. However, the heparin group were older, and more of them 
had congestive cardiac failure and chronic respiratory problems.

In a 2001 retrospective study of patients with echo evidence of RV dysfunction, Hamel ${ }^{38}$ compared 64 patients treated with thrombolysis with 64 treated with heparin. There were no deaths or bleeding complications in the heparin group, but haemorrhage occurred in $15.6 \%$ of the thrombolysed group, and $6.3 \%$ died.

In a 2002 randomised trial of 256 patients with PE and evidence of RV dysfunction (defined by echocardiography, right heart catheterisation, or ECG changes), Konstantinides $^{39}$ found a 30 day mortality of $3.4 \%$ in those receiving $100 \mathrm{mg}$ reteplase over 2 hours plus heparin and $2.2 \%$ in those treated with heparin alone $(p=0.71)$. The mortality in this study was unexpectedly low. There was only one fatal bleed in the heparin group and bleeding complications were not statistically different between the two groups.

Echocardiography is a widely available bedside test which helps diagnosis, risk stratification, and exclusion of alternate diagnoses such as RV infarct, aortic dissection, and pericardial effusion/tamponade..$^{40}$

\section{WHICH IS THE THROMBOLYTIC OF CHOICE?}

Six trials (table 3 ) with 481 patients have compared various thrombolytic regimens using rTPA, streptokinase, and urokinase, with rTPA being delivered over 2 hours and urokinase and streptokinase delivered over $2-24$ hours. ${ }^{42-47}$ No one agent has proved superior. ${ }^{44}$

rtPA regimens showed better pulmonary flow at 2 hours but not subsequently compared with long and short regimens using the other agents. ${ }^{43}{ }^{45-47}$ Goldhaber ${ }^{48}$ compared rTPA at a dose of $100 \mathrm{mg}$ over 2 hours with the same agent at $0.6 \mathrm{mg} /$ $\mathrm{kg}$ over 15 minutes, and found similar improvements in all parameters as measured by echo, angiography, and VQ scan.

Tebe $^{49}$ compared rTPA 100 mg over 2 hours with Reteplase (rTPA) 10 units at baseline and repeated at 30 minutes, and found no difference in all measured pulmonary haemodynamics.

In conclusion, no single agent or regimen has been shown to be more effective than any other, though the theoretical risk of worsening hypotension with streptokinase in patients with circulatory compromise suggests other thrombolytic agents may be preferable.

\section{HOW SHOULD THROMBOLYTICS BE ADMINISTERED?}

Despite the theoretical advantages of higher local concentration at the clot site, the delivery of thrombolysis via pulmonary artery catheter offers no advantage in terms of mortality, morbidity, or haemorrhage risk over peripheral administration and carries the risks of a more invasive procedure, according to the results of a single trial. ${ }^{50}$ Bolus therapy may be expected to produce more rapid thrombolysis with improved outcome but two trials found this method of administration offered no advantage over infusion regimens. ${ }^{4851}$ Overall, it thus appears there is insufficient evidence to justify the increased risk.

\section{WHAT ARE THE COMPLICATIONS OF THROMBOLYSIS?}

The major complication of thrombolysis is haemorrhage, although allergy, hypotension, fever, nausea, and vomiting may occur. ${ }^{52}$ The overall risk of haemorrhage with thrombolysis is reported as $6-20 \%$, with no significant differences between the alternative agents.

The most feared bleeding complication is intracerebral haemorrhage, which has a reported incidence of 0.6$3 \% .^{14} 3553-55$ The risk factors associated with intracranial bleeding are increasing age $(0.4 \%$ at $<65$ years and $2.1 \%$ at $>75$ years), increasing dose of thrombolytic, chronic hypertension, female sex, low body mass (with weight $<70 \mathrm{~kg}$ being associated with a four fold increase), and pulmonary catheterisation. $^{53} 55$

The risk of bleeding largely defines the contraindications to thrombolysis. These relative contraindications are active bleeding, any active or recent (within 6 weeks) intracranial disease, trauma, visceral biopsy, surgery, or gastrointestinal bleed, haemorrhagic disorder, hepatic or renal failure, pregnancy, puncture of a non-compressable vessel, and pericarditis. ${ }^{1456}$

Table 3 Randomised trials comparing the efficiency and safety of thrombolytic agents

\begin{tabular}{|c|c|c|c|c|c|c|}
\hline Study & $\begin{array}{l}\text { No. of } \\
\text { patients }\end{array}$ & Treatment regimens & $\begin{array}{l}\text { Mortality, } \\
\text { n (\%) }\end{array}$ & $\begin{array}{l}\text { Recurrence } \\
\text { n (\%) }\end{array}$ & $\begin{array}{l}\text { Major } \\
\text { haemorrhage, n } \\
(\%)\end{array}$ & Comments \\
\hline \multirow[t]{3}{*}{$\begin{array}{l}\text { USET phase } \\
2^{42}\end{array}$} & 59 & $\begin{array}{l}\text { UK } 2000 \text { U/lb bolus, } 2000 \text { U/ } \\
\text { lb/h over } 12 \text { hours }\end{array}$ & $4(7)$ & $1(1)$ & $8(14)$ & \multirow[t]{3}{*}{$\begin{array}{l}\text { Angiographic diagnosis, repeated at } \\
24 \mathrm{~h} \text { showing improved pulmonary } \\
\text { flow in UK group but equal at day } 5\end{array}$} \\
\hline & 54 & $\begin{array}{l}\text { UK } 2000 \mathrm{U} / \mathrm{lb} \text { bolus, } 2000 \mathrm{U} / \\
\mathrm{lb} / \mathrm{h} \text { over } 24 \text { hours }\end{array}$ & $5(9)$ & 4 (7) & $10(19)$ & \\
\hline & 54 & $\begin{array}{l}\text { SK } 250000 \text { unit bolus, } \\
100000 \mathrm{U} / \mathrm{h} \text { over } 24 \text { hours }\end{array}$ & $5(9)$ & $2(4)$ & $6(11)$ & \\
\hline \multirow[t]{2}{*}{$\begin{array}{l}\text { Goldhaber et } \\
\text { al } 1988^{43}\end{array}$} & 23 & $\begin{array}{l}\text { UK } 2000 \mathrm{U} / \mathrm{lb} \text { bolus, } 2000 \mathrm{U} / \\
\mathrm{lb} / \mathrm{h}\end{array}$ & $2(8.7)$ & $1(4)$ & $11(48)$ & \multirow[t]{2}{*}{$\begin{array}{l}\text { Perfusion/haemodynamics better at } \\
2 \mathrm{~h} \text { in rTPA but equal by } 24 \mathrm{~h} \text {. Trend } \\
\text { towards more haemorrhage UK }\end{array}$} \\
\hline & 22 & Rt-PA $100 \mathrm{mg}$ over 2 hours & $2(8.7)$ & 0 & $4(18)$ & \\
\hline \multirow[t]{2}{*}{$\begin{array}{l}\text { Meyer et al } \\
1992^{44}\end{array}$} & 29 & $\begin{array}{l}\text { UK } 4400 \mathrm{U} / \mathrm{lb} \text { bolus, } 4400 \mathrm{U} / \\
\mathrm{lb} / \mathrm{h} \text { over } 24 \text { hours }\end{array}$ & $1(3.4)$ & $2(6.9)$ & $8(28)$ & \multirow[t]{2}{*}{$\begin{array}{l}2 \mathrm{~h} \text { pulmonary haemodynamics } \\
\text { favour rTPA but equal at } 12 \mathrm{~h}\end{array}$} \\
\hline & 34 & Rt-PA $80-100 \mathrm{mg}$ over 2 hours & $3(8.8)$ & $2(5.9)$ & $7(21)$ & \\
\hline \multirow[t]{2}{*}{$\begin{array}{l}\text { Goldhaber et } \\
\text { al } 1992^{45}\end{array}$} & 46 & $\begin{array}{l}\text { UK } 1000000 \mathrm{U} \text { over } 10 \mathrm{mins} \text {, } \\
2000000 \mathrm{U} \text { over } 110 \mathrm{mins}\end{array}$ & $1(2)$ & $3(6.5)$ & $6(13)$ & \multirow[t]{2}{*}{$\begin{array}{l}\text { No difference at } 2 \mathrm{~h} \text { angiogram or } \\
24 \mathrm{~h} \text { perfusion scan }\end{array}$} \\
\hline & 44 & Rt-PA $100 \mathrm{mg}$ over 2 hours & $2(4.5)$ & 0 & $9(20)$ & \\
\hline \multirow[t]{2}{*}{$\begin{array}{l}\text { Meneveau et } \\
\text { al } 1997^{46}\end{array}$} & 25 & $\begin{array}{l}\text { SK } 250000 \text { bolus, } \\
1000000 \mathrm{U} / \mathrm{h} \text { over } 12 \text { hours }\end{array}$ & $1(4)$ & $2(8)$ & $3(12)$ & \multirow[t]{2}{*}{$\begin{array}{l}2 \mathrm{~h} \text { pulmonary haemodynamics } \\
\text { favour rTPA but no difference by } \\
12 \mathrm{~h}\end{array}$} \\
\hline & 25 & Rt-PA $100 \mathrm{mg}$ over 2 hours & $1(4)$ & 0 & $4(16)$ & \\
\hline \multirow[t]{2}{*}{$\begin{array}{l}\text { Meneveau et } \\
\text { al } 1998^{47}\end{array}$} & 43 & SK 1500000 U 2 hours & 0 & $1(2.3)$ & $3(7.0)$ & \multirow[t]{2}{*}{$\begin{array}{l}\text { Identical haemodynamics at } 2 \mathrm{~h} \text { and } \\
\text { identical day } 2 \text { perfusion scan }\end{array}$} \\
\hline & 23 & Rt-PA & 0 & $2(8.7)$ & $5(21.7)$ & \\
\hline
\end{tabular}




\section{WHAT ARE THE ALTERNATIVES TO THROMBOLYSIS IN CRITICALLY SICK PATIENTS?}

Given the risk of haemorrhage with thrombolysis and the improving surgical techniques, alternative methods of treating massive PE have been explored, including pulmonary catheterisation and surgical embolectomy. The former has been shown to improve cardiac output and has a mortality of $11 \%$ with a "success" rate of $91 \%$ in a series of non-shocked patients with moderate to severe RV dysfunction. ${ }^{57}$ Cardiac catheterisation, mechanical fragmentation techniques, high velocity jet fragmentation, and combinations of mechanical clot disruption with low/usual dose thrombolysis have all been described in case reports/case series but there is no published trial evidence. ${ }^{58-65}$ It is unlikely that adherent clot more than $48-72$ hours old is removable. ${ }^{58} 59$

There is no randomised trial of medical versus surgical therapy. Surgical embolectomy has been used on critically ill patients and when thrombolysis is contraindicated. Perioperative mortality rates are reported as $29-44 \%$ in this group. ${ }^{66}{ }^{67}$ Gulba $^{68}$ reported a series of 23 surgically and 24 medically treated patients with systolic blood pressure $<100 \mathrm{mmHg}$, and reported survival rates of $77 \%$ and $67 \%$ respectively. In a series of 29 patients including those with RV dysfunction but normal systolic blood pressure, Aklog ${ }^{69}$ reported a mortality of $11 \%$ at 1 month.

\section{CONCLUSIONS}

- The use of thrombolysis in cardiac arrest thought to be due to pulmonary embolus is supported by the available evidence and appears to improve survival to hospital discharge in one study. ${ }^{36}$

- Thrombolysis may be beneficial in patients with massive PE with systemic hypotension and this approach is widely supported, ${ }^{70}$ although good quality evidence for mortality benefit is lacking.

- In those without shock but with RV dysfunction on echo, there are studies showing more rapid clot lysis and faster normalisation of cardiac function when treated by thrombolysis/heparin as opposed to heparin alone, ${ }^{15} 19$ but thrombolysis has not been shown to reduce mortality and in this subgroup and confers a risk of haemorrhage. Thrombolysis should only be used in these patients on an individual basis with careful consideration of opposing risk factors.

- For emboli with no cardiovascular compromise, thrombolysis is not advisable.

\section{Authors' affiliations}

T Harris, Royal Melbourne Hospital, Australia

S Meek, North Bristol NHS Trust, Bristol, UK

Competing interests: none declared

\section{REFERENCES}

1 Oger E. Incidence of venous thromboembolism in a community-based study in western France. Thromb Haemost 2000;83:657-60.

2 Modam B, Sharon E, Jelin W. Factors contributing to the incorrect diagnosis of pulmonary embolism. Chest 1972;62:388-93.

3 Morpurgo M, Schmid C. Clinico-pathological correlations in pulmonary embolism. A prospective evaluation. Prog Respir Res 1980;13:8-15.

4 Pineda LA, Hathwar VS, Grant BJ. Clinical suspicion of fatal pulmonary embolism. Chest 2001;120:791-5.

5 Giuyini C, Ricco G, Marini C, et al. Updates in pulmonary embolism: epidemiology. Chest 1995; 107(suppl):3-9.

6 Hull RD, Rushob GE, Carter CJ, et al. Pulmonary embolism I outpatients with pleuritc chest pain. Arch int Med 1988;148:838-44.

7 Pollak EW, sparks FC, Warber WF. Pulmonary embolism: an appraisal of 516 cases. Arch Surg 1972;107:66-8.

8 Barritt DW, Jordan SC. Anti coagulant drugs in the treatment of pulmonary embolism-a controlled trial. Lancet 1960;1:1309-12.
9 Goldhaber SZ, Visanai L, DeRosa M, for ICOPER. Acute pulmonary embolism: clinical outcomes of the International Cooperative Pulmonary Embolism Registry. Lancet 1999;353:1389-89.

10 Meyer G, Brenot F, Pacouret G, et al. Subcutaneous low molecular weight heparin versus intravenous unfractionated heparin in the treatment of acute non massive pulmonary embolism. An open randomized pilot study. Haemost 1995; 74:1432-35.

11 The Columbus Investigators. Low molecular weight heparin in the treatment of patients with venous thromboembolism. N Engl J Med 1997;337:657-62.

12 Simonneau G, Sors H, Charbonnier S for the THESEE study group. A comparison of low molecular weight heparin with unfractionated heparin for acute pulmonary embolism. N Engl J Med 1997;337:663-9.

13 Dalen JE, Banas JS, Brook HK, et al. Resolution rate of acute pulmonary embolism in mice. N Engl J Med 1969;280:1194-99.

14 Arcasoy SM, Kreit JW. Thrombolytic therapy for pulmonary embolism-a comprehensive review of the current evidence. Chest 1999;1 15:1695-707.

15 Alpert JS, Smith R, Carlson J, et al. Mortality in patients treated for pulmonary embolism. JAMA 1976;236:1477-80.

16 Goldhaber SZ, Haire WD, Feldstein ML, et al. Alteplase versus heparin in acute pulmonary embolism: randomized trial assessing right ventricular function and pulmonary perfusion. Lancet 1993;341:507-11.

17 Kasper W, Konstantinides S, Greibel A, et al. Management strategies and determinants of outcome in acute pulmonary embolism: results of a multicenter registry. J Am Coll Cardiol 1997;30:1 165-71.

18 Kasper W, Konstantinides S, Greibel A, et al. Prognostic significance of right ventricular afterload stress detected by echocardiography in patients with clinically suspected pulmonary embolism. Heart 1997;77:346-9.

19 Konstantinides S, Giebel A, Oleschewski M, et al. Association between thrombolytic treatment and the prognosis of haemodynamically stable patients with major pulmonary embolism - results of a multicenter registry. Circulation 1997:96:882-8.

20 Urokinase Pulmonary Embolism Trial. Phase 1 results - a cooperative study. JAMA 1970;214:2163-72.

21 Tibbutt DA, Davies JA, Anderson JA, et al. Comparison by controlled clinical trial of streptokinase and heparin in the treatment of life threatening pulmonary embolism. BMJ 1974;1:343-7.

22 Ly B, Arnesen $\mathrm{H}$, Erie $\mathrm{H}$, et al. A controlled trial of streptokinase and heparin in the treatment of major pulmonary embolism. Acta Med Scand 1978;203:465-70.

23 Marini C, Di Ricco G, Rosso G, et al. Fibrinolytic effects of urokinase and heparin in acute pulmonary embolism: a randomized clinical trial. Respiration 1988;54:162-73.

24 PIOPED Investigators. Tissue plasminogen activator for the treatment of acute pulmonary embolism: a collaborative study by the PIOPED Investigators. Chest 1990;97:528-33.

25 Levine M, Hirsh J, Weitz J, et al. A randomized trial of a singe bolus regimen of recombinant tissue plasminogen activator in patients with acute pulmonary embolism. Chest 1990:1473-9.

26 Dalla-Volta S, Palla A, Santolicandro A, et al. PAIMS 2: alteplase combined with heparin vs heparin in the treatment of pulmonary embolism: Plasminogen Activator Italian Multicenter study 2. J Am Coll Cardiol 1992;20:520-6.

27 Goldhaber SZ, Haire WD, Feldstein ML. Alteplase versus heparin in acute pulmonary embolism: randomized trial assessing right ventricular function and pulmonary perfusion. Lancet 1993;341:507-1 1.

28 Jerges-Sanchez C, Ramirez-Rivera A, Garcia M de L, et al. Streptokinase and heparin versus heparin alone in massive pulmonary embolism; a randomized controlled trial. J Thromb Thrombolysis 1995;2:227-9.

29 Konstantinides S, Geibel A, Heusel G, et al. Heparin plus alteplase compared with heparin alone in patients with sub massive pulmonary embolism. NEJM 2002;347:1143-50.

30 Thabut G, Thabut D, Myers RP, et al. Thrombolytic therapy for pulmonary embolism-A meta analysis. JACC 2002;40:1660-67.

31 Agnelli G, Becattini C, Kirschstein T. Thrombolysis vs heparin in the treatment of pulmonary embolism. A clinical outcome-based meta-analysis. Arch Intern Med 2002; 162:2537-41.

32 Carson JL, Kelly MA, Duff A, et al. The clinical course of pulmonary embolism. N Engl J Med 1992;326:1240-45.

33 Goldhaber SZ. Pulmonary embolism-broadening the paradigm for its administration. Circulation 1997;96:716-18.

34 Robertson C, Steen P, Bircher N, et al. The 1998 European Resuscitation Guidelines for adult advanced life support: as statement from the working group on ALS, and approved by the executive committee of the European resusitation council. Resuscitation 1998;1998:81-90.

35 Newman DH, Greenwald I, Callaway CW. Cardiac arrest and the role of thrombolytic agents. Ann Emerg Med 2000;35:472-80

36 Bottiger BW, Bode C, Kern S. Efficacy and safety of thrombolytic therapy after initially unsuccessful cardiopulmonary resuscitation: a prospective clinical trial. Lancet 2001;357:1583-5.

37 Bailen MR, Cuadra JA, De Hoyes EA. Thrombolysis during CPR in fulminant pulmonary embolism: a review. Crit Care Med 2001;29:221 1-19.

38 Hamel E, Pacouret G, Vincentelli D, et al. Thrombolysis or heparin in massive pulmonary embolism with right ventricular dilation. Chest 2001;120:120-5.

39 Konstinides S, Giebel A, Heusel G, et al. Heparin plus alteplase compared with heparin alone in patients with submassive pulmonary embolism. N Engl J Med 2002;347:1143-50.

40 Wittlich W, Erbel A, Eichla S, et al. Detection of central pulmonary artery thromboemboli by transeosophegeal echocardiography in patients with severe PE. J Am Soc Echocardiography 1992;5:514-25.

41 John M, Furlong R, Schrank K. Diagnostic use of emergency department echo in massive PE. Ann Emerg Med 1992;21:260-3. 
42 USET phase 2-urokinase-streptokinase trial: phase 2 results. JAMA 1974;229:1606-13.

43 Goldhaber S, Kessler C, Heit J, et al. Randomized controlled trial of riPA versus urokinase in the treatment of acute pulmonary embolism. Lancet 1988;2:293-8.

44 Meyer G, Surs H, Charbonnier B, et al. Effects of intravenous urokinase versus alteplase on the total pulmonary resistance in acute massive pulmonary embolism: a European double blind trial. J Am Cardiol 1992;19:239-45.

45 Goldhaber S, Kessler C, Heit J, et al. Recombinant tissue-type plasminogen activator versus a novel dosing régime of urokinase in acute pulmonary embolism: a randomized controlled multicenter trial. J Am Coll Cardiol 1992;20:24-30.

46 Meneveau N, Schiele F, Vuillemenot A, et al. Streptokinase versus alteplase in massive PE: a randomized trial assessing right heart haemodynamics and pulmonary vascular obstruction. Eur Heart J 1997; 18:1141-48.

47 Meneveau N, Schiele F, Metz D, et al. Comparative efficiency of a 2 hour regimen of streptokinase versus alteplase in acute massive pulmonary embolism: immediate clinical and haemodynamic outcomes and one year follow up. J Am Coll Cardiol 1998:31:1057-63.

48 Goldhaber S, Agnelli G, Levine M, et al. Reduced dose bolus alteplase vs conventional alteplase infusion in massive pulmonary embolism: an international multicenter randomized trial. Chest 1994;106:718-24.

49 Tebe V, Graf A, Kambe W, et al. Haemodynamic effects of double bolus reteplase versus alteplase infusion in massive pulmonary embolism. Am HeartJ 1999; 137:39-44.

50 Verstraete $M$, Miller G, Bounameaux $H$, et al. Intravenous and intrapulmonary recombinant tissue-type plasminogen activator in the treatment of acute massive pulmonary embolism. Circulation 1988;77:353-60.

51 Sors H, Pacouret G, Azarian R, et al. Haemodynamic effects of bolus vs 2-h infusion of alteplase in acute massive pulmonary embolism: a randomized controlled multicenter trial. Chest 1994;106:712-17.

52 Gulba D, Bode C, Runge M, et al. Thrombolytics-an overview. Ann Haematol 1996;73(suppl):519-27.

53 Mikkola K, Patel s, Parker J, et al. Increasing age is a risk factor for haemorrhagic complications after pulmonary embolism. Am Heart J 1997; 134:69-72.

54 Dalen J. thrombolytic therapy for pulmonary embolism, is it effective? Is it safe? When is it indicated? Arch Int Med 1997;157:2250-6.

55 Kanter D, Mikkola K, Patel S, et al. Thrombolytic therapy for pulmonary embolism - frequency of intracranial haemorrhage and associated risk factors. Chest 1997;111:1241-45.
56 Janata-Schwatczek K, Weiss K, Reizinger I, et al. Pulmonary embolism 2. Diagnosis and treatment. Sem Thromb Haemost 1996;22:33-52.

57 Greenfield L. Catheter pulmonary Embolectomy. Chest 1991;100:593-4.

58 Isoda. A case of acute massive pulmonary embolism treated by mechanical clot fragmentation using percutaneous angioplasty balloon. Jpn Circ J 1997;61:531-5.

59 Koning R, Cribier A, Gerber L, et al. A new treatment for severe pulmonary embolism:percutaneous rheolytic thrombectomy. Circulation 1997;96:2498-500.

60 De Gregorio M, Gimeno M, Mainar A, et al. Mechanical and enzymatic thrombolysis for acute massive pulmonary embolism. J Vasc Interv Radiol 2002;13:163-9.

61 Muller-Hulsbeck S, Brossmann J, Jahnke T, et al. Mechanical thrombectomy of major and massive pulmonary embolism with use of Amplatz thrombectomy device. Invest Radiol 2001;36:317-22.

62 Fava M, Loyola S, Heute I. Massive pulmonary embolism:treatment with hydrolysis thrombectomy catheter. J Vasc Interv Radiol 2000;11:1159-64.

63 Stock K, Jacob A, Schnabel K, et al. Massive pulmonary embolism: treatment with thrombus fragmentation and local fibrinolysis with rtPA. Cardiovasc Interv Radiol 1997;20:364-8.

64 Fava M, Loyola S, Flores $P$, et al. Mechanical fragmentation and pharmacological thrombolysis for massive pulmonary embolism. J Vasc Interv Radiol 1997:8:261-6.

65 Schmitz-Rode T, Janssens U, Schild H, et al. Fragmentation of massive pulmonary embolism using a pig rotation catheter. Chest 1998;114:1427-8.

66 Clark D, Abrams L. Pulmonary embolectomy. A 25-year experience. J Thorac Cardiovasc Surg 1986;92:442-5.

67 Doerge $H$, Schoendole T, Voss $M$, et al. Surgical therapy for fulminant pulmonary embolism: early and late results. Thorac Cardiovasc Surg 1999:47:9-13.

68 Gulba D, Schmid C, Borst H, et al. Medical compared to surgical treatment of massive pulmonary embolism. Lancet 1994;343:576-7.

69 Aklog L, Williams C, Byrne J, et al. Acute pulmonary embolectomy-a contempary approach. Circulation 2002;105:1416-22.

70 Miller, AC. British Thoracic Society Standards of Care Committee Pulmonary Embolism Guideline Development Group. British Thoracic Society guidelines for the management of suspected acute pulmonary embolism. Thorax 2003; 58:470-84 